\title{
Research
}

\section{Rules Compliance and Age: Experimental Evidence with Fishers from the Amazon River}

\author{
Maria Alejandra Velez ${ }^{1}$ and Maria Claudia Lopez ${ }^{2}$
}

\begin{abstract}
We report the results of common-pool resource economic experiments conducted with indigenous communities in the Colombian Amazon. The experiments recreate two contexts: a limited open access with no institutions regulating the fisheries and a nonmonetary external regulation that limits individual extraction when a fisher is found to be overextracting. We find that variables that did not explain behavior under limited open access do so under the regulatory institution. In particular, when the nonmonetary external regulation was introduced, we found a nonlinear significant effect of age on individual harvest. This result implies a negative relationship between age and individual extraction that reaches a peak around age 54. Our results suggest that in our sample, age groups react differently to an institution aimed to manage the fishery and open a discussion regarding the role of older fishers when a new regulation is introduced to manage natural resources. Their role could go beyond the dissemination of traditional knowledge and cultural systems since older fishers could be key actors in disseminating and adapting new institutions.
\end{abstract}

Key Words: age; common-pool resources; field experiments, regulations; social dilemmas

\section{INTRODUCTION}

In several indigenous communities of the Amazon region and in other parts of the world, the institutions for managing natural resources are cultural and symbolic (Wagley 1953, Reichel-Dolmatoff 1971, Ross 1978, Descola 1996, Berkes et al. 2000, Turner et al. 2000). This traditional knowledge implies an understanding of the workings of ecological systems (Turner and Berkes 2006) and is based on "a cumulative body of knowledge, practice and belief, evolving by adaptive processes and handed down through generations by cultural transmission" (Berkes 1999:8).

In this context, the role of older adults as the holders of cultural knowledge is determinative in local communities because they transmit it to younger generations. In recent decades, however, the process of market integration and other processes of cultural exchange have affected this traditional knowledge by altering social and cultural systems in many indigenous communities (Sandner 2003). Sandner (2003:274) for example, argues that local leaders in Kuna indigenous communities in Panama have lost their authority, and it is possible to observe that "traditional ecological knowledge and underlying cosmological concepts including a general respect for nature lose importance and transmission from one generation to the other is interrupted." With similar results, Sáenz-Arroyo et al. (2005) interviewed fishers from three generations in the Gulf of California, showing that perceptions and knowledge regarding the fishery change across age groups. One of their main conclusions is that the knowledge about the fishery held by the oldest of the three generations needs to be disseminated to the generation of young fishers to assure the persistence of the ecosystem in the future.

The indigenous communities of Ticunas, Cocamas, and Yaguas in the Colombian Amazon municipality of Puerto Nariño, where livelihoods depend mainly on the extraction of natural resources, are facing similar situations. In these communities, artisanal fishing in Tarapoto Lake is important both for family consumption and as a source of income. However, loss of traditional and cultural knowledge and population growth have increased the pressure on resources, affecting the management of Tarapoto Lake and its resources (Formulación del Plan de Manejo - Humedales 2007, internal document, Universidad Nacional de Colombia, Sede Amazonia). The lack of a monitoring system and proper management rules for fishery activities are endangering their sustainability.

Fishing in Tarapoto Lake, and in the entire Colombian Amazon region, is managed through national regulations that fail to consider where fishing occurs or if it is conducted during periods of heavy rainfall when the lakes connect to the Amazon River or dry seasons when they are isolated. Seasonal restrictions for key species are common throughout the region, but monitoring is either weak or nonexistent. For that reason, local and environmental authorities, indigenous leaders, and local environmental nongovernment organizations (NGOs) decided to develop a fishery comanagement plan for Tarapoto Lake.

\footnotetext{
${ }^{1}$ Facultad de Administracion, Universidad de los Andes, Bogotá, Colombia, ${ }^{2}$ Department of Community Sustainability, Michigan State University, USA
} 
In the context of this process, we were invited by Fundación Omacha, a local NGO, to conduct common-pool resource (CPR) economic experiments with fishers from around the lake and explore the effects of different institutions. Economic experiments are controlled decision games used to address economic questions (Friedman and Sunder 1994). In particular, common-pool economic experiments involve a dilemma between acting individually or cooperatively in the use of shared natural resources (Poteete et al. 2010). Our experiments were designed to resemble the social dilemma faced by rural communities when extracting their resources. Participants decide individually how many units (strings of fish) they want to extract from Tarapoto Lake. The social dilemma is captured because the individual extraction implies a negative externality for the rest of the group.

We conducted a framed field experiment based on Harrison and List's (2004) taxonomy in the municipality of Puerto Nariño with 75 fishers from three communities of Tarapoto Lake during three sessions in April 2009. In each session we had 25 participants from one community distributed in groups of five. The experimental sessions and subsequent discussions were part of the activities promoted by the local NGO aiming to solve overfishing by discussing the consequences of an open-access regime and the effects of different institutions. Some studies suggest that field experiments act as a pedagogical tool (Moreno-Sánchez and Maldonado 2010), help participants become more conscious of the consequences of their decisions (Cardenas and Carpenter 2008; M. C. Lopez unpublished manuscript), and facilitate the dialogue among stakeholders involved in the management of resources (Anderies et al. 2011).

We explore the behavior of indigenous fishers and the effect of age in two contexts: (1) limited open access and (2) nonmonetary external regulation. Our baseline protocol, the limited open-access context, where decisions are made without regulations but access is limited to group members, replicates the design by Velez et al. (2009) in which five users make simultaneous harvesting decisions without any rules to restrict individual behavior during the first ten rounds. In the following ten rounds, we explore the effect of an external nonmonetary regulation with imperfect enforcement.

The nonmonetary external regulation consists of an individual harvest quota that was set to maximize the group's payoff (Velez et al. 2010). After each round, there was a 10\% probability that individuals' extractions would be audited and those found not complying with the regulation were forced to extract a minimum amount of the resource in the following round. The imperfect enforcement was similar to that used by Cardenas et al. (2000) and Velez et al. (2010) and resembles the modest and weak external (formal) enforcement found in developing countries.

In our experiments, we found that under limited open access average individual extraction was above the group optimal but less than predicted by the purely self-interest Nash equilibrium. External regulation effectively decreased individual extraction but did not attain the social optimum. Moreover, we found no significant effect from age on individual decisions under the limited open-access treatment. Yet when the nonmonetary external regulation was introduced, we found a nonlinear significant effect of age on individual harvest. It was negative and significant until age 54, when the relationship between age and individual harvest changed and became positive. This change does not imply that older participants had the highest extraction levels of our sample. This result implies that older participants extract on average more than those between 50 and 54 years old but about the same as participants between 40 and 49 years old and less than participants 40 years old and younger.

Our results could be explained following the framework proposed by Cardenas and Ostrom (2004), which, as opposed to a model based on self-regarding motives, suggests that participants in economic experiments make their decisions based not only on the monetary incentives (material pay-off layer) but also on the group and institutional contexts (group layer) and information about themselves (identity layer). Under this framework, as Cardenas and Ostrom (2004:309) suggest, the "layers of information are differentially invoked by the structure of a situation to inform the decision on whether to cooperate or defect." Thus, variables that did not explain behavior under limited open access do so under our regulatory institution. Our results seem to show that the external nonmonetary regulation made explicit some information that induced old participants to change their behavior when the regulation was introduced.

The relationship between age and compliance in a natural resource setting also has been explored by other studies with consistent results. Brick et al. (2011) report a nonlinear relationship between age and risk attitudes in coastal communities in South Africa. In particular, the authors show that there is a peak of risk aversion. Thus older fishers are more risk averse than younger fishers and are less likely to catch illegally relative to their more risk-loving counterparts.

Agarwal (2009a) argues that complying with a rule reflects time preferences in the sense that the more you need the resource to survive the less you will follow the rules because your short-term needs are greater than your long-term horizon. It would be reasonable to conjecture that older adults, having 
already overcome the problem of survival and reproduction, find it easier to follow rules than the young generation. Agarwal (2009b) describes this emphasis in the importance of forest protection as a conservationist idea that comes with age. Madrigal-Ballestero et al. (2012) found in a turtle egg harvesting community in Costa Rica that different factors, including individual dependence on the income from the sale of eggs, perceptions and legitimacy of rules and demographic factors such as age and gender are determinant factors to explain rule-breaking behavior. In particular, the authors found that age positively affects compliance with rules because elders invested time and effort to get government approval to harvest eggs and to design the set of rules currently in use.

Our results contribute to ongoing efforts to understand compliance behavior in fisheries and other CPR dilemmas where more attention needs to be paid to the effect of individual socioeconomic and demographic characteristics on decision making. As stated by Poteete et al. (2010) and Janssen (2010), a better knowledge of microsituational characteristics and the broader context is required to explain individual behavior and compliance in the use of CPRs (Ostrom 1990, 2007, Agrawal 2001). This understanding is prerequisite to developing more effective and inclusive management strategies (Hauck 2009).

In the case of the indigenous communities in the Colombian Amazon whose livelihoods depend on fishing in Tarapoto Lake, our results suggest that new institutional design promoted by external and internal actors should focus on the youngest to increase compliance. In this context, older adults could play a role in designing and adapting new institutions to manage the resources since they are aware of the need for new regulatory systems to manage their fisheries.

\section{RELATED LITERATURES}

\section{Effect of age in the experimental literature}

List (2004) and Sutter and Kocher (2007) affirm that the relationship between age and social preferences such as trust, altruism, and cooperation is mostly unexplored. ${ }^{[1]}$ Both studies also agree that the understanding of this relationship is relevant for economic theorists, empirical researchers, practitioners, and policy makers. List (2004) finds in three field environments (a public good, a natural experiment, and an experiment similar to a prisoner dilemma) that there is a relationship between age and prosocial behavior since older subjects cooperate more than younger participants. Sutter and Kocher (2007) found that trust in strangers increases almost linearly from childhood to early adulthood but reaches a peak somewhere around the age of 30 or 40 . However, the authors suggest that this result needs further exploration.
Also, in a metastudy for the dictator game, Engel (2011) found that age has a strong effect in explaining sharing results. In particular, Engel (2011:599) reports that “....For people of middle age, the equal split is the mode, while for the elderly this is giving everything".

In CPR experiments conducted with rural population in Colombia, Velez et al. (2010) report that age has a negative and significant relationship with extractions under different institutions (including external regulation and communication). Castillo et al. (2011) found that age has a negative and significant relationship in the baseline condition (open access) and under different institutions such as a rotation system and an elected quota.

Only a handful of field experiments have been conducted with indigenous populations in the Amazon region (Henrich 2000, Gurven 2004, Henrich and Smith 2004, Patton 2004, Sirén et al. 2006). The majority of these studies did not find age to be significant in determining behavior and cooperation. Only Sirén et al. (2006) report that preferences in a lottery game change dramatically with age.

\section{External regulations in the experimental literature}

Several studies in the experimental literature explore the effects of external monetary regulations on CPR games (Ostmann 1998, Beckenkamp and Ostmann 1999, Cardenas et al. 2000, Velez et al. 2010). In general, these studies report that an external monetary regulation does not achieve the social optimum and may even crowd out cooperation (Cardenas et al. 2000). The experimental literature also explores the effects of nonmonetary regulations in social dilemmas. Lopez et al. (2012) created an experiment to test the effectiveness of social emotions such as shame or guilt to generate cooperation in social dilemmas. These nonmonetary regulations seem to increase cooperation without the financial harm of the monetary regulations.

Cinyabuguma et al. (2005) use a voluntary contribution mechanism experiment that allows members of the group to permanently expel other members (a nonmonetary sanction) by voting at the end of each round. Expelled members could not return to their groups but continued to participate in the experiment by joining a group composed of other expelled players. When this nonmonetary sanction was introduced, subsequent contributions to the public good were higher than in a baseline treatment, reaching levels of contribution of approximating $100 \%$ of the endowment. Güth et al. (2007) introduced a public-good experiment that gave a leader the power of exclusion if a member was not cooperating, a power that significantly increased cooperation.

Our design differs from most external regulations, which include monetary penalties; we explore an external regulation that limits individual extraction when someone is found to be 
overextracting. It also differs from other nonmonetary regulations experiments because the results of the inspections were kept private, meaning that shame could not explain the results. Finally and more important, our design followed suggestions made by the NGO that had invited us to conduct the experiments. From their discussions with fishers in the Tarapoto Lake, it was clear that they did not want a monetary-penalty sanctioning system to enforce their management rules. ${ }^{[2]}$ Some studies (e.g., Jenny et al. 2007) have shown that the types and dimensions of control and enforcement need to be meaningful for the fishers to promote compliance. With fishers in Denmark, Nielsen and Mathiesen (2003) found that perception of the meaningfulness and efficacy of the regulation is determinant for rule compliance; individuals comply with rules when they perceive them as fair and consistent with their norms. Therefore, we used an external regulation that was consistent with fishers' expectations about new institutional arrangements to manage their fishery.

\section{CONTEXT}

The municipality of Puerto Nariño in the Colombian Amazon consists mainly of indigenous communities in rural collective territories known locally as resguardos. More than 95\% of the population lives in the rural area, and the rest, a mix of indigenous, white, and mestizo, are in the "urban" area (Formulación del Plan de Manejo - Humedales 2007, internal document, Universidad Nacional de Colombia, Sede Amazonia), which is simply a central point for the school, hospital, and political authorities accessible only by river. The two most important economic activities in the municipality are fishing and wood extraction (Ochoa et al. 2006).

Vieco and Oyuela (1997) established that elders of these communities play an important role in the unity and wellbeing of the community. Each of the 21 communities, including the urban area, has a local-level, governing cabildo menor indígena, which consists of a curaca (top local indigenous authority) and cabildantes (council members) who are elected by community members once per year. The cabildos menores compose a major assembly known as the cabildo mayor that elects the curaca mayor (major indigenous authority) at the municipality level (Formulación del Plan de Manejo - Humedales 2007, internal document, Universidad Nacional de Colombia, Sede Amazonia). The elders of the communities advise and mentor the cabildos, but over the years, for various reasons, their role has changed. Puerto Nariño is an important tourist destination, and the municipality has been integrated to different markets, which has diminished the elders' power and authority. Even though most of the municipality belongs to the indigenous communities through the resguardos, which includes the right to manage their territory, different conservation organizations are working in the area and the Colombian environmental authorities continue to regulate the fisheries.

Participants in the first session of our experiment came from the urban area and neighboring Ticoya Resguardo. These participants are more integrated into the market economy than participants in the other two sessions; commercial boats depart daily from Puerto Nariño to big towns along the Amazon River. Fishers here use nets and sell the fish to restaurants, schools, and the local population; in this community, fishing is an important source of income and a subsistence activity.

Participants in the second session also belong to the Ticoya Resguardo and live close to Tarapoto Lake and Loreroyacu River. They are the least connected to the market economy, having no electrical power or refrigeration facilities. Such conditions imply more frequent fishing. These participants continue to practice traditional arrow fishing and travel longer distances to fish. In general, they do not have alternative activities to mitigate the decimation of their resources.

In the last session, most participants were fishers who live close to the Amazon River but do not belong to the Ticoya Resguardo. The main economic activity of this community is handicrafts manufacturing. They fish in the Amazon River for consumption either with nets or arrows but not daily because they can refrigerate their catch. They sometimes fish in Tarapoto Lake.

All participants had similar schooling (about five years) and most were male, as the recruitment had targeted fishers. Average age was 41 , with one participant reporting age 15 and the rest between 17 and 70, and most were from the Ticuna ethnic group. Across the three sessions, we found similar levels of participation in community and fishers' organizations (25\% and $8 \%$, respectively), and $61 \%$ of participants recognized the existence of some kind of agreement to manage the fisheries in Tarapoto Lake. The only significant difference across sessions was the average number of days fished during the week. Participants in the second session fished 3.8 days per week on average, which is significantly different $(p=0.08$ using a two-sample Mann-Whitney test) from the average 2.9 days per week in the third session. However, the differences between the first and second sessions and between the first and third sessions were not statistically significant (see Table $1)$.

\section{EXPERIMENT DESIGN}

Subjects participated in a 20-round CPR experiment framed as a decision about harvesting from Tarapoto Lake. Prior to conducting the experiments, the instructions (see Appendix) were discussed with indigenous authorities to obtain consent and adjust the language and framing to local characteristics 
Table 1. Participants's sociodemographic characteristics

\begin{tabular}{|c|c|c|c|c|}
\hline Variable $^{\dagger}$ & Session 1 & Session 2 & Session 3 & All sessions \\
\hline$\overline{\text { Age }}$ & 43.4 & 40.1 & 38.7 & 40.7 \\
\hline Percent male & $88 \%$ & $92 \%$ & $96 \%$ & $92 \%$ \\
\hline Education & 5.4 & 4.9 & 5.4 & 5.2 \\
\hline Market integration & High & Low & Medium & \\
\hline Fishing gear & Nets & Arrows & Nets and arrows & \\
\hline Purpose of fishing & Source of income & Subsistence & Subsistence & \\
\hline Percent in a fishers' organization & $12 \%$ & $4 \%$ & $8 \%$ & $8 \%$ \\
\hline $\begin{array}{l}\text { Percent of fishers in a community } \\
\text { organization }\end{array}$ & $28 \%$ & $24 \%$ & $24 \%$ & $25 \%$ \\
\hline Number of days fishing per week. & 3.4 & 3.8 & 2.9 & 3.3 \\
\hline $\begin{array}{l}\text { Percent agreement - percent of } \\
\text { participants who know agreements exist to } \\
\text { manage the fisheries }\end{array}$ & $54 \%$ & $64 \%$ & $64 \%$ & $61 \%$ \\
\hline $\begin{array}{l}\text { Percent seasonal restrictions - percent of } \\
\text { participants who know seasonal } \\
\text { restrictions exist }\end{array}$ & $75 \%$ & $88 \%$ & $72 \%$ & $78.4 \%$ \\
\hline
\end{tabular}

${ }^{\dagger}$ For all variables, there were 25 observations per session except in Percent agreement and Percent seasonal restriction in Session 1, where we had 24 observations in each.

(survey and forms are available upon request). Our experiment used the CPR design and earnings table reported in Velez et al. (2009). Each subject decides how many strings of fish to extract from a CPR based on the earnings table shown in Table 2. In this setting, the standard symmetric Nash equilibrium is achieved when each individual chooses to harvest seven units, while the social optimum (where group earnings is maximized) is two units.

In each round of the experiment, each fisher had to decide and write his or her extraction decision on a "decision card". Then the experimenter collected the decision cards from the whole group, summed the extractions, and announced each group's total. With this information, but without knowing other participants' individual decisions, each participant calculated the extraction of others in order to identify his or her payoff on the earning table. Each participant was then asked to keep a record of earnings on the individual "calculation sheet".

Participants knew who the other members of their group were, but individuals' decisions were kept private by the researchers. Each group played a first stage with ten rounds of a limited open-access CPR game without communication or external regulation; the second stage of ten rounds introduced a nonmonetary external regulation with imperfect enforcement. Participants also played five rounds that combined the last treatment with communication, but we do not report those rounds in this article. The external regulation consisted of an individual harvest quota of two units, the level that maximized the group's payoff. To enforce the quota, each participant faced a monitoring probability of
$10 \%$, determined by pulling a ballot from a bag containing five ballots with participants' identification numbers and five blank ballots. Participants who were inspected and harvesting more than the quota (two units) faced a mandatory minimum extraction (one unit) in the next round. All participants knew who was inspected, but the individuals' harvest decisions and sanctions, if any, were kept private. To avoid any other effects, such as shame, the audited participants always filled out extraction decision cards, even when sanctioned and forced to extract only one unit.

The experiment started with the researcher reading instructions aloud and handing out the forms for recording decisions. To make the instructions and forms easier to understand, all procedures were illustrated with posters. Experimenters and well-trained research assistants answered participants' questions about the mechanics of the experiment in private. Participants were asked to remain silent for the entire experiment and to sit so they could not see other participants' forms. We also conducted practice rounds. If a participant had difficulties writing or calculating earnings, he or she was assisted but had to make his or her own decisions. We did not keep records of who was helped.

Recruitment was conducted by the local NGO and targeted to fishers older than 18. All sessions were run by the same researcher and we tried to guarantee that members of the same family did not participate in the same group. Experiments lasted for three hours and average earnings per person (paid on the day of the experiment) were equivalent to U.S. $\$ 8.60$, which covered the opportunity cost of participants in the area. $^{[3]}$ 
Table 2. Earnings table

\begin{tabular}{|c|c|c|c|c|c|c|c|c|c|}
\hline \multirow[b]{2}{*}{ Amount fished by others } & \multicolumn{9}{|c|}{ My amount fished } \\
\hline & 1 & 2 & 3 & 4 & 5 & 6 & 7 & 8 & 9 \\
\hline 4 & 900 & 996 & 1087 & 1172 & 1252 & 1326 & 1395 & 1458 & 1516 \\
\hline 5 & 882 & 976 & 1064 & 1146 & 1223 & 1295 & 1361 & 1421 & 1476 \\
\hline 6 & 864 & 955 & 1040 & 1120 & 1194 & 1263 & 1326 & 1384 & 1436 \\
\hline 7 & 846 & 934 & 1017 & 1094 & 1165 & 1231 & 1292 & 1347 & 1396 \\
\hline 8 & 829 & 914 & 994 & 1068 & 1137 & 1200 & 1258 & 1310 & 1357 \\
\hline 9 & 811 & 893 & 970 & 1042 & 1108 & 1168 & 1223 & 1273 & 1317 \\
\hline 10 & 793 & 873 & 947 & 1016 & 1079 & 1137 & 1189 & 1236 & 1277 \\
\hline 11 & 775 & 852 & 923 & 989 & 1050 & 1105 & 1154 & 1198 & 1237 \\
\hline 12 & 757 & 831 & 900 & 963 & 1021 & 1073 & 1120 & 1161 & 1197 \\
\hline 13 & 739 & 811 & 877 & 937 & 992 & 1042 & 1086 & 1124 & 1157 \\
\hline 14 & 721 & 790 & 853 & 911 & 963 & 1010 & 1051 & 1087 & 1117 \\
\hline 15 & 703 & 769 & 830 & 885 & 934 & 978 & 1017 & 1050 & 1077 \\
\hline 16 & 686 & 749 & 807 & 859 & 906 & 947 & 983 & 1013 & 1038 \\
\hline 17 & 668 & 728 & 783 & 833 & 877 & 915 & 948 & 976 & 998 \\
\hline 18 & 650 & 708 & 760 & 807 & 848 & 884 & 914 & 939 & 958 \\
\hline 19 & 632 & 687 & 736 & 780 & 819 & 852 & 879 & 901 & 918 \\
\hline 20 & 614 & 666 & 713 & 754 & 790 & 820 & 845 & 864 & 878 \\
\hline 21 & 596 & 646 & 690 & 728 & 761 & 789 & 811 & 827 & 838 \\
\hline 22 & 578 & 625 & 666 & 702 & 732 & 757 & 776 & 790 & 798 \\
\hline 23 & 560 & 604 & 643 & 676 & 703 & 725 & 742 & 753 & 758 \\
\hline 24 & 543 & 584 & 620 & 650 & 675 & 694 & 708 & 716 & 719 \\
\hline 25 & 525 & 563 & 596 & 624 & 646 & 662 & 673 & 679 & 679 \\
\hline 26 & 507 & 543 & 573 & 598 & 617 & 631 & 639 & 642 & 639 \\
\hline 27 & 489 & 522 & 549 & 571 & 588 & 599 & 604 & 604 & 599 \\
\hline 28 & 471 & 501 & 526 & 545 & 559 & 567 & 570 & 567 & 559 \\
\hline 29 & 453 & 481 & 503 & 519 & 530 & 536 & 536 & 530 & 519 \\
\hline 30 & 435 & 460 & 479 & 493 & 501 & 504 & 501 & 493 & 479 \\
\hline 31 & 417 & 439 & 456 & 467 & 472 & 472 & 467 & 456 & 439 \\
\hline 32 & 400 & 419 & 433 & 441 & 444 & 441 & 433 & 419 & 400 \\
\hline 33 & 382 & 398 & 409 & 415 & 415 & 409 & 398 & 382 & 360 \\
\hline 34 & 364 & 378 & 386 & 389 & 386 & 378 & 364 & 345 & 320 \\
\hline 35 & 346 & 357 & 362 & 362 & 357 & 346 & 329 & 307 & 280 \\
\hline 36 & 328 & 336 & 339 & 336 & 328 & 314 & 295 & 270 & 240 \\
\hline
\end{tabular}

Note: The social optimum (2) and the Nash equilibrium (7) were not in bold in the table given to participants.

\section{EXPERIMENT RESULTS}

We start by presenting the average of individual extraction and earnings by treatment. Consistent with previous field experiments (Velez et al. 2009, 2010), individual extraction under limited open access (6.1 on average) deviated from the Nash Equilibrium (7.0) but was above the social optimum (2.0). When the regulation is introduced, the average extraction level decreased to 3.07 , which is significantly different from the result under limited open access at the $1 \%$ level of significance using a Mann-Whitney test (Table 3). As expected, the lower level of individual extraction in the regulation treatment implied significantly higher earnings than those obtained under limited open access as reported in Table 4 . These results were consistent across sessions. The effect of including a regulation in the second ten rounds is shown graphically in Figure 1.
Fig. 1. Average extraction per round

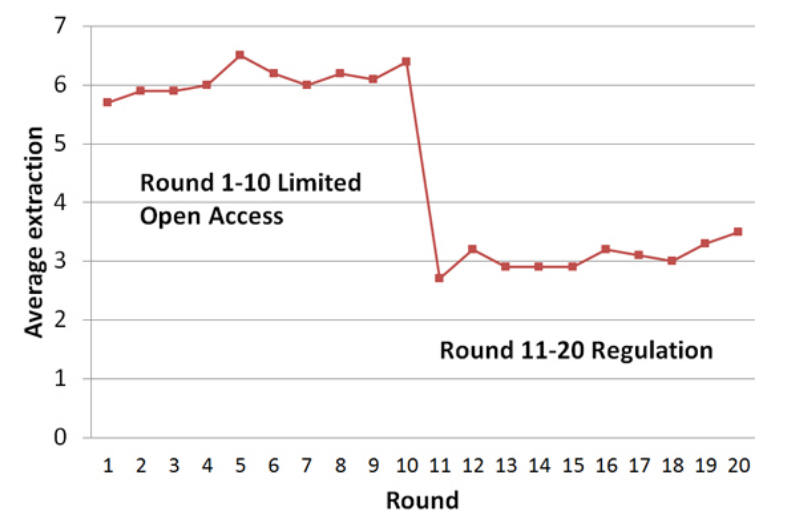


Table 3. Average level of extractions under limited open access and regulation

\begin{tabular}{lcccc}
\hline \hline Treatment & Session 1 & Session 2 & Session 3 & All sessions \\
\hline Limited open access & 5.73 & 6.49 & 6.09 & 6.10 \\
Regulation & 2.46 & 3.35 & 3.40 & 3.07 \\
Limited open access vs. & $(<0.01)^{* * *}$ & $(<0.01)^{* * *}$ & $(<0.01)^{* * *}$ & $(<0.01)^{* * *}$ \\
regulation using a Mann-Whitney & & & & \\
test & 250 & 250 & 250 & 750 \\
Number of observations & & & \\
\hline
\end{tabular}

*** denotes $p<0.01 ; * *$ denotes $p<0.05 ; *$ denotes $p<0.10$

To explore the effects of age, we conducted an econometric analysis of individual repeated decisions over the ten rounds in each treatment controlled by sociodemographic characteristics and fixed effects by sessions and groups. First, we explored the individual harvest for the first ten rounds with an individual random Tobit effect model to control for individual differences and censored data, since individual harvest decisions go from 1 to 9 (Model 1 in Table 5). Neither age nor age squared nor other demographic characteristics significantly explained extraction. The variable round had a positive and significant effect, which implies a decrease in cooperation over time. Sessions 2 and 3 had a positive and significant effect over extraction compared to Session 1 (default). We did not find a statistically significant difference between Sessions 2 and $3(p=0.91) .{ }^{[4]}$ Being married, having children, and size of household could also be important to explain individual behavior, but we did not ask those questions; further research might explore the effects of these variables and their relationships with age.

We ran another individual random effect Tobit model to explore individual extraction in the second ten rounds (Model 2 in Table 5). The number of observations in Model 2 was lower than in Model 1 because Model 2 did not include sanctioned participants in the round in which they were forced to extract one unit.

In Model 2, we found a negative and significant effect of age on individual harvest $(-0.32)$, but the effect of age slowly changed as age increased, as indicated by the small although positive and significant effect of age squared (0.003). By setting the partial derivate of age to zero, we found that the age at which participants reached the minimum level of extraction was 53.3 years old; after this point they started to increase their individual harvest, which is consistent with the existence of a peak in trust games reported by Sutter and Kocher (2007). However, as show in Figure 2, this did not mean that older participants (more than 54 years) extracted the highest levels; it just means that after that point the relationship between age and individual harvest changed and became positive. This positive effect implied that participants 55 years old and older extract on average more than those between 50 and 54 but less than participants 40 years old and younger. Yet the overall effect of age on individual harvest (partial derivate with respect to age), taking into account the average age of our sample (41 years old), was -0.07 (i.e., an additional year decreases individual extraction by 0.07 units).

Fig. 2. Age average extraction

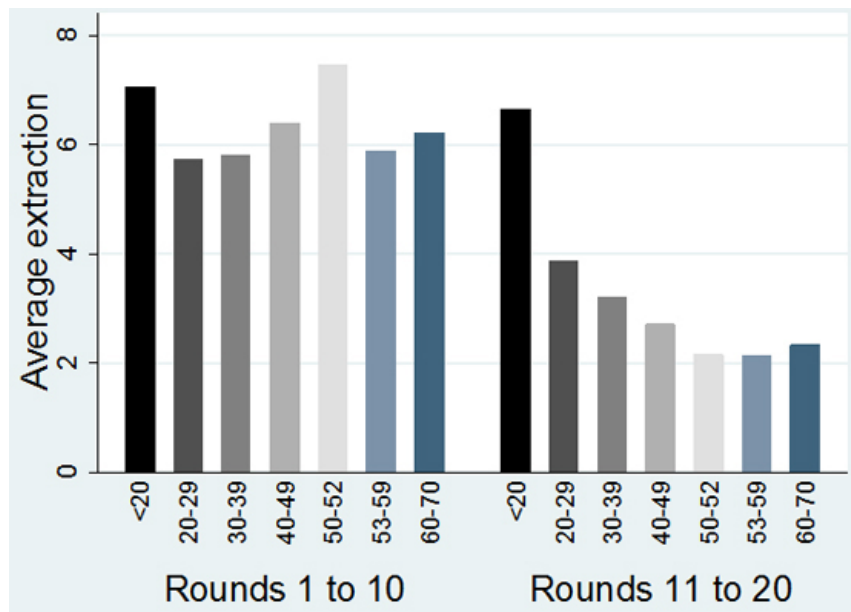

We also found that participants who knew about the existence of seasonal restrictions extracted significantly less under the regulation. The variable round maintained a positive and significant effect. Other sociodemographic characteristics were not statistically significant. We did not find any difference across sessions.

In Model 2, age, age squared, and knowing about seasonal restrictions not only became significant under regulation but changed signs with respect to the results in Model 1 under limited open access. This result is consistent with the idea that 
Table 4. Average earnings under limited open access and regulation

\begin{tabular}{|c|c|c|c|c|}
\hline Treatment & Session 1 & Session 2 & Session 3 & All sessions \\
\hline Limited open access & 704 & 610 & 673 & 662 \\
\hline Regulation & 910 & 876 & 873 & 886 \\
\hline $\begin{array}{l}\text { Limited open access vs. } \\
\text { regulation using a Mann-Whitney } \\
\text { test }\end{array}$ & $(<0.01)^{* * *}$ & $(<0.01)^{* * *}$ & $(<0.01)^{* * *}$ & $(<0.01)^{* * *}$ \\
\hline Number of observations & 250 & 250 & 250 & 750 \\
\hline
\end{tabular}

participants make their decisions based on three layers of information: identity (information about themselves), group context, and material payoff (Cardenas and Ostrom 2004). The group layer acknowledged that decisions are influenced by other players (e.g., shared norms) and raised the possibility that they may meet in the future. The identity layer included individual information such as gender, age, and other-regarding preferences.

In that sense, our results suggest that the external nonmonetary regulation made explicit some information that induced participants to change their behavior from one institution to the other. For example, knowing about the existence of seasonal restrictions influenced behavior under regulation, reducing extraction by 1.1 units, but not under limited open access. Participants who knew the existence of seasonal restrictions cooperated more under a regulation than under limited open access, where there was a lack of reference to a regulatory scheme. Cardenas and Ostrom (2004) found a similar result in CPR experiments conducted with rural villagers in Colombia. They report that participants who believe a "state" organization should manage the local commons will extract proportionally less when an external regulation is introduced in the game but extract more when face-to-face communication is allowed.

Yet what is interesting in our results is why age, a variable belonging to the identity layer according to Cardenas and Ostrom's (2004) framework, was negative and statistically significant under regulation and not under a limited openaccess structure (see Figure 2). A possible explanation could be suggested by Sutter and Kocher's (2007) finding. That is, the nonmonetary regulations may evoke some social preferences that older participants may have. These preferences are not necessarily evoked in the limited openaccess baseline since under this institution no reference is made to evoke a cooperative behavior to achieve the social optimum or to follow any rule.

To confirm our results and to test the differences across treatments, we conducted two new random effect Tobit models, pooling the data from Models 1 and 2. In Model 3 (Table 6), we included a dummy variable for the regulation treatment and confirmed that this institution reduced the level of extraction by 4.2 units with respect to the limited open access captured by the constant. In Model 4 (Table 6), we included interactions between age, age squared, and knowledge of seasonal restrictions with the dummy variable for the regulation treatment. The dummy's coefficient was positive and significant. However, this result is not capturing the net effect of the regulatory treatment. The derivative of individual harvest with respect to regulation in this case will depend on the media and distribution of age, round number, and knowledge of seasonal restrictions. With Model 4, we confirmed that age and knowledge of seasonal restrictions under regulation had a negative and significant effect on individual extraction and age squared had a positive and significant effect compared to the limited open-access treatment (the default).

\section{DISCUSSION}

In common-pool experiments conducted in the Colombian Amazon, we found that age is an important variable that explains individual behavior when a nonmonetary regulation is introduced. The regulatory institution invoked different effects of age on individual harvest. Those effects were not significant under limited open access.

This result is relevant in indigenous communities, because it suggests that when traditional and cultural systems are weakened or affected by external factors, fishers' responses to new institutions are not age homogenous. Several testable hypotheses could explore this relationship between age and rule compliance: (1) As age increases, participants could view laws featuring this type of regulation as "reminders" about what should be done (Tyran and Feld 2006). (2) Older members of a community may comply with rules more often than younger members because their decisions reflect their time preferences (Agarwal 2009a,b). In this hypothesis, older participants already have overcome the issue of survival and cooperate more often than the youngest participants, who are still building families. (3) Older adults may comply more with 
Table 5. Random effects Tobit estimation of individual extraction (standard error in parentheses)

\begin{tabular}{|c|c|c|}
\hline Variable & $\begin{array}{c}\text { Model } 1 \text { - } \\
\text { limited open access }\end{array}$ & $\begin{array}{l}\text { Model } 2 \text { - } \\
\text { regulation }\end{array}$ \\
\hline Constant (default is Session 1) & $\begin{array}{c}1.60 \\
(2.89)\end{array}$ & $\begin{array}{l}11.46 * * * \\
(2.63)\end{array}$ \\
\hline Age (years) & $\begin{array}{c}0.03 \\
(0.11)\end{array}$ & $\begin{array}{c}-0.32 * * * \\
(0.09)\end{array}$ \\
\hline Age squared & $\begin{array}{c}-0.00002 \\
(0.001)\end{array}$ & $\begin{array}{c}0.003 * * \\
(0.001)\end{array}$ \\
\hline Education (years of formal schooling) & $\begin{array}{c}0.08 \\
(0.13)\end{array}$ & $\begin{array}{l}-0.16 \\
(0.12)\end{array}$ \\
\hline Male & $\begin{array}{c}0.99 \\
(0.86)\end{array}$ & $\begin{array}{c}0.44 \\
(0.78)\end{array}$ \\
\hline Fishers' organization & $\begin{array}{c}0.73 \\
(0.79)\end{array}$ & $\begin{array}{l}-0.57 \\
(0.71)\end{array}$ \\
\hline Community organization & $\begin{array}{c}0.41 \\
(0.59)\end{array}$ & $\begin{array}{c}0.06 \\
(0.54)\end{array}$ \\
\hline Number of days fishing per week & $\begin{array}{l}-0.06 \\
(0.17)\end{array}$ & $\begin{array}{l}-0.18 \\
(0.16)\end{array}$ \\
\hline Agreement & $\begin{array}{l}-0.23 \\
(0.49)\end{array}$ & $\begin{array}{c}0.50 \\
(0.45)\end{array}$ \\
\hline Knowledge of seasonal restrictions & $\begin{array}{c}0.60 \\
(0.58)\end{array}$ & $\begin{array}{c}-1.12^{* * *} \\
(0.53)\end{array}$ \\
\hline Dummy Session 2 & $\begin{array}{l}2.88 * * \\
(1.24)\end{array}$ & $\begin{array}{l}-0.67 \\
(1.12)\end{array}$ \\
\hline Dummy Session 3 & $\begin{array}{l}2.74 * * \\
(1.11)\end{array}$ & $\begin{array}{l}-0.28 \\
(1.02)\end{array}$ \\
\hline Round & $\begin{array}{l}0.07 * * \\
(0.03)\end{array}$ & $\begin{array}{c}0.08 * * * \\
(0.02)\end{array}$ \\
\hline Fixed effects by groups (not reported) & 14 & 14 \\
\hline $\begin{array}{c}\text { Rho } \\
\text { Prob }>\chi^{2} \\
N\end{array}$ & $\begin{array}{l}0.26 \\
0.37 \\
730\end{array}$ & $\begin{array}{l}0.42 \\
0.00 \\
706\end{array}$ \\
\hline
\end{tabular}

Note: The dependent variable is the individual's harvest (1-9, inclusive). For regulation, we do not include participants in the round in which they were forced to extract one unit.

*** denotes $p<0.01 ; * *$ denotes $p<0.05$; * denotes $p<0.10$

regulations because they have invested time and effort in discussions regarding how to regulate the fishery (MadrigalBallestero et al. 2012). (4) Older fishers are more risk averse than younger fishers and thus more likely to comply with rules (Brick et al. 2011).

This paper points out the need to do new experiments with a different range of ages and cultural backgrounds to specifically test the effect of different institutions aiming to promote cooperation among users of natural resources. They will allow us to understand the relations and interactions between these variables and social preferences. That way, new behavioral models that account for these complex relations can be developed. It should be interesting to also replicate our experiments to explore their generalizability to other traditional communities.
Our findings open up the discussion regarding the role of adults and elders in traditional communities when a new regulation is introduced to manage natural resources. Even though elders might have lost some influence, these old fishers still could play an important role in the support and dissemination of new regulations even when they are not based on traditional rules. New formal regulations, often promoted by external actors, could strengthen rather than diminish the role of local leaders and elders of the community.

With new management strategies, a key part of the process is re-embedding responsibilities for resource management in local communities (Sandner 2003 citing Hanna and Jentoft 1996). Our results show, for fishers of Tarapoto Lake, that either the importance of these new formal regulatory institutions needs to be stressed to the youngest members of 
Table 6. Pooled random effects Tobit estimation of individual extraction (standard error in parentheses)

\begin{tabular}{|c|c|c|}
\hline Variable & $\begin{array}{c}\text { Model } 3 \text { - } \\
\text { limited open access \& regulation }\end{array}$ & $\begin{array}{c}\text { Model } 4 \text { - } \\
\text { limited open access \& regulation }\end{array}$ \\
\hline Constant (default is open access) & $\begin{array}{l}9.1 * * * \\
(1.95)\end{array}$ & $\begin{array}{c}5.33 * * * \\
(2.05)\end{array}$ \\
\hline Dummy regulation & $\begin{array}{l}-4.23 * * * \\
(0.26)\end{array}$ & $\begin{array}{l}3.32 * * \\
(1.39)\end{array}$ \\
\hline Age (years) & $\begin{array}{c}-0.17 * * \\
(0.07)\end{array}$ & $\begin{array}{l}-0.03 \\
(0.08)\end{array}$ \\
\hline Age squared & $\begin{array}{c}0.001^{*} \\
(0.0008)\end{array}$ & $\begin{array}{c}0.0004 \\
(0.0009)\end{array}$ \\
\hline Age (years) x Dummy regulation & & $\begin{array}{c}-0.27 * * * \\
(0.06)\end{array}$ \\
\hline Age squared $\mathrm{x}$ Dummy regulation & & $\begin{array}{c}0.002 * * * \\
(0.0007)\end{array}$ \\
\hline Education (years of formal schooling) & $\begin{array}{l}-0.05 \\
(0.09)\end{array}$ & $\begin{array}{l}-0.05 \\
(0.08)\end{array}$ \\
\hline Male & $\begin{array}{c}0.72 \\
(0.58)\end{array}$ & $\begin{array}{c}0.69 \\
(0.58)\end{array}$ \\
\hline Fishers' organization & $\begin{array}{l}-0.06 \\
(0.53)\end{array}$ & $\begin{array}{l}-0.06 \\
(0.53)\end{array}$ \\
\hline Community organization & $\begin{array}{c}0.17 \\
(0.40)\end{array}$ & $\begin{array}{c}0.17 \\
(0.40)\end{array}$ \\
\hline Number of days fishing per week & $\begin{array}{l}-0.14 \\
(0.12)\end{array}$ & $\begin{array}{l}-0.13 \\
(0.12)\end{array}$ \\
\hline Agreement & $\begin{array}{c}0.16 \\
(0.34)\end{array}$ & $\begin{array}{c}0.15 \\
(0.34)\end{array}$ \\
\hline Knowledge of seasonal restriction & $\begin{array}{l}-0.24 \\
(0.39)\end{array}$ & $\begin{array}{c}0.21 \\
(0.42)\end{array}$ \\
\hline $\begin{array}{l}\text { Knowledge of seasonal restrictions x Dummy } \\
\text { regulation }\end{array}$ & & $\begin{array}{c}-0.92 * * * \\
(0.31)\end{array}$ \\
\hline Dummy Session 2 & $\begin{array}{c}0.97 \\
(0.84)\end{array}$ & $\begin{array}{c}0.97 \\
(0.84)\end{array}$ \\
\hline Dummy Session 3 & $\begin{array}{c}1.25 \\
(0.76)\end{array}$ & $\begin{array}{l}1.25^{*} \\
(0.76)\end{array}$ \\
\hline Round & $\begin{array}{c}0.07 * * * \\
(0.02)\end{array}$ & $\begin{array}{c}0.07 * * \\
(0.03)\end{array}$ \\
\hline Round $\mathrm{x}$ Regulation & & $\begin{array}{c}0.02 \\
(0.04)\end{array}$ \\
\hline Fixed effects by groups (not reported) & 14 & 14 \\
\hline Rho & 0.13 & 0.14 \\
\hline Prob $>\chi^{2}$ & 0.00 & 0.00 \\
\hline$N$ & 1436 & 1436 \\
\hline
\end{tabular}

Note: The dependent variable is the individual's harvest (1-9), inclusive. For regulation, we do not include participants in the round in which they were forced to extract one unit.

$* * *$ denotes $p<0.01$; ** denotes $p<0.05$; * denotes $p<0.10$

the community (e.g., through educational programs or other participatory processes) or new institutions more appropriate to this age group need to be tested and developed. Therefore, an important topic for future research is to investigate the kinds of institutions that younger fishers in the community will be more apt to comply with, without affecting the cooperation already found in older adults.
Responses to this article can be read online at: http://www.ecologyandsociety.org/issues/responses. $\mathrm{php} / 5721$ 


\section{Acknowledgments:}

We thank Fundación Omacha, especially Catalina Trujillo, for help in coordinating all the logistics for the experiments. We are grateful to Adriana Molina for her research assistance. We appreciate the thoughtful comments and suggestions of Emilio Moran, Roger Madrigal, Juan Camilo Cardenas, and three anonymous reviewers. We especially thank all the participants in the experiments. Funding for these experiments and fieldwork came from Fundacion Omacha, WWF Colombia, and the School of Management, Los Andes University.

\section{LITERATURE CITED}

Agarwal, B. 2009a. Rule making in community forestry institutions: the difference women make. Ecological Economics 68(8-9): 2296-2306. [online] URL: http://www. sciencedirect.com/science/article/pii/S0921800909000767

Agarwal, B. 2009b. Gender and forest conservation: the impact of women's participation in community forest governance. Ecological Economics 68: 2785-2799 http://dx. doi.org/10.1016/j.ecolecon.2009.04.025

Agrawal, A. 2001. Common property institutions and sustainable governance of resources. World Development 29 (10): 1649-1672. [online] URL: http://www.sciencedirect. com/science/article/pii/S0305750X01000638 http://dx.doi. org/10.1016/S0305-750X(01)00063-8

Anderies, J. M., M. A. Janssen, F. Bousquet, J.-C. Cardenas, D. Castillo, M.-C. Lopez, R. Tobias, B. Vollan, and A. Wutich. 2011. The challenge of understanding decisions in experimental studies of common pool resource governance. Ecological Economics 70(9): 1571-1579. [online] URL: http://www.sciencedirect.com/science/article/pii/ S0921800911000188 http://dx.doi.org/10.1016/j. ecolecon.2011.01.011

Beckenkamp, M., and A. Ostmann. 1999. Missing the target? Sanctioning as an ambiguous structural solution. Pages 165180 in M. Foddy, M. Smithson, S. Scheneider, and M. Hogg, editors. Resolving social dilemmas: dynamic, structural, and intergroup aspects. Psychology Press, Philadelphia, Pennsylvania, USA.

Berkes, F. 1999. Sacred ecology: traditional ecological knowledge and resource management. Taylor \& Francis, Philadelphia, Pennsylvania, USA.

Berkes, F., J. Colding, and C. Folke. 2000. Rediscovery of traditional ecological knowledge as adaptive management. Ecological Applications 10: 1251-1262. [online] URL: http://www.esajournals.org/doi/pdf/10.1890/1051-0761(2000) 010\%5B1251\%3AROTEKA\%5D2.0.CO\%3B2 http://dx.doi. org/10.1890/1051-0761(2000)010[1251:ROTEKA]2.0.CO;2

Brick, K., M. Visser, and J. Burns. 2011. Risk aversion: experimental evidence from South African fishing communities. Working paper 227. University of Cape Town, Rondebosch, South Africa. [online] URL: http://econrsa.org/ home/index.php?option=com docman\&task=

doc_download $\&$ gid=336\&Itemid=67 http://dx.doi.org/10.1093/ ajae/aar120

Cardenas, J. C., and J. Carpenter. 2008. Behavioural development economics: lessons from field labs in the developing world. Journal of Development Studies 44(3): 311-338. [online] URL: http://www.tandfonline.com/doi/ full/10.1080/00220380701848327 http://dx.doi. org/10.1080/00220380701848327

Cardenas, J. C., and E. Ostrom. 2004. What do people bring into the game? Experiments in the field about cooperation in the commons. Agriculture Systems 82(3): 307-326. [online] URL: http://www.indiana.edu/ workshop/reprints/R04_27. pdf http://dx.doi.org/10.1016/j.agsy.2004.07.008

Cardenas, J. C., J. K. Stranlund, and C. E. Willis. 2000. Local environmental control and institutional crowding-out. World Development 28(10): 1719-1733. [online] URL: http://www. sciencedirect.com/science/article/pii/S0305750X00000553 http:// dx.doi.org/10.1016/S0305-750X(00)00055-3

Castillo D., F. Bousquet, M. A. Janssen, K. Worrapimphong, and J. C Cardenas. 2011. Context matters to explain field experiments: results from Colombian and Thai fishing villages. Ecological Economics 70(9): 1609-1620. [online] URL: http://www.sciencedirect.com/science/article/pii/

S092180091100200X http://dx.doi.org/10.1016/j.

ecolecon.2011.05.011

Cinyabuguma, M., T. Page, and L. Putterman. 2005. Cooperation under the threat of expulsion in a public goods experiment. Journal of Public Economics 89: 1421-1435. [online] URL: http://www.sciencedirect.com/science/article/ pii/S0047272704001616

Croson, R. 2005. The method of experimental economics. International Negotiation 10(1): 131-148. http://dx.doi. org/10.1163/1571806054741100

Descola, P. 1996. In the society of nature. Cambridge University Press, Cambridge, UK.

Engel, C. 2011. Dictator games: a meta study. Experimental Economics 14(4): 583-610. [online] URL: http://www. springerlink.com/content/c7327p2r2j3v0076/ 
Friedman, D., and S. Sunder. 1994. Experimental methods: a primer for economists. Cambridge University Press, Cambridge, UK. http://dx.doi.org/10.1017/CBO9781139174176

Gurven, M. 2004. Does market exposure affect economic game behavior? The ultimatum game and the public goods game among the Tsimane of Bolivia. Pages 194-231 in J. Henrich, R. Boyd, S. Bowles, C. Camerer, E. Fehr, and H. Gintis, editors. Foundations of human sociality: economic experiments and ethnographic evidence from fifteen smallscale societies. Oxford University Press, Oxford, UK.

Güth, W., M. V. Levati, M. Sutter, and E. van der Heijden. 2007. Leading by example with and without exclusion power in voluntary contribution experiments. Journal of Public Economics 91(5-6): 1023-1042. [online] URL: http://www. sciencedirect.com/science/article/pii/S0047272706001538 http:// dx.doi.org/10.1016/j.jpubeco.2006.10.007

Harrison, G. W., and J. List. 2004. Field experiments. Journal of Economic Literature 42(4): 1009-1055. http://dx. doi.org/10.1257/0022051043004577

Hauck, M. 2009. Policy brief towards small-scale fisheries compliance in South Africa. Environmental Evaluation Unit, University of Cape Town, Rondebosch, South Africa.

Henrich, J. 2000. Does culture matter in economic behavior? Ultimatum game bargaining among the Machiguenga of the Peruvian Amazon. American Economic Review 90(4): 973979.

Henrich, J., and N. Smith. 2004. Comparative experimental evidence from Machiguenga, Mapuche, Huinca, and American populations. Pages 125-168 in J. Henrich, R. Boyd, S. Bowles, C. Camerer, E. Fehr, and H. Gintis, editors. Foundations of human sociality: economic experiments and ethnographic evidence from fifteen smallscale societies. Oxford University Press, Oxford, UK. http://dx.doi. org/10.1093/0199262055.003.0005

Janssen, M. 2010. Introducing ecological dynamics into common-pool resource experiments. Ecology and Society 15 (2): 7. [online] URL: http://www.ecologyandsociety.org/ vol15/iss $2 / \operatorname{art} 7 /$.

Jenny, A, F. Hechavarria Fuentes, and H.-J. Mosler. 2007. Psychological factors determining individual compliance with rules for common pool resource management: the case of a Cuban community sharing a solar energy system. Human Ecology 35(2): 239-250. [online] URL: http://www. springerlink.com/content/ulp20t2656n715j7/fulltext.pdf http:// dx.doi.org/10.1007/s10745-006-9053-x

List, J. 2004. Young, selfish and male: field evidence of social preferences. The Economic Journal 114: 121-149. http://dx.doi.org/10.1046/j.0013-0133.2003.00180.x
Lopez, M. C., J. J. Murphy, J. M. Spraggon, and J. K. Stranlund. 2012. Comparing the effectiveness of regulation and pro-social emotions to enhance cooperation: experimental evidence from fishing communities in Colombia. Economic Inquiry 50(1): 131-142. [online] URL: http://onlinelibrary. wiley.com/doi/10.1111/j.1465-7295.2010.00344.x/pdf

Madrigal-Ballestero, R. , Schlüter, A. and Lopez, M. C. 2012 "What Makes them Follow the Rules? Empirical Evidence from Turtle Egg Harvesters in Costa Rica. Marine Policy, http://dx.doi.org/10.1016/j.marpol.2012.05.009. http://dx.doi. org/10.1016/j.marpol.2012.05.009.

Moreno-Sánchez, R. del P., and J. H. Maldonado. 2010. Evaluating the role of co-management in improving governance of marine protected areas: an experimental approach in the Colombian Caribbean. Ecological Economics 69(12): 2557-2567. [online] URL: http://www.sciencedirect. com/science/article/pii/S0921800910002983

Nielsen, J. R., and C. Mathiesen. 2003. Important factors influencing rule compliance in fisheries lessons from Denmark. Marine Policy 27(5): 409-416. [online] URL: http://www.sciencedirect.com/science/article/pii/ $\underline{\text { S0308597X03000241 }}$

Ochoa, G., C. Zarate, and A. Wood. 2006. Puerto Nariño: el pueblo que se mira en el río. Retos al desarrollo sustentable en los municipios amazónicos. Publicaciones ILSA. Bogota, Colombia.

Ostmann, A. 1998. External control may destroy the commons. Rationality and Society 10: 103-122. http://dx.doi. org/10.1177/104346398010001005

Ostrom, E. 1990. Governing the commons: the evolution of institutions for collective action. Cambridge University Press, Cambridge, UK. http://dx.doi.org/10.1017/CBO9780511807763

Ostrom, E. 2007. A diagnostic approach for going beyond panaceas. Proceedings of the National Academy of Sciences of the United States of America 104: 15181-15187. [online] URL: http://www.pnas.org/content/104/39/15181.full.pdf+ $\underline{\text { html http://dx.doi.org/10.1073/pnas.0702288104 }}$

Patton, J. Q. 2004. Coalitional effects on reciprocal fairness in the ultimatum game: a case from the Ecuadorian Amazon. Pages 96-124 in J. Henrich, R. Boyd, S. Bowles, C. Camerer, E. Fehr, and H. Gintis, editors. Foundations of human sociality: economic experiments and ethnographic evidence from fifteen smallscale societies. Oxford University Press, Oxford, UK. http://dx.doi.org/10.1093/0199262055.003.0004

Poteete, A. R., M. Janssen, and E. Ostrom. 2010. Working together: collective action, the commons and multiple methods in practice. Princeton University Press, Princeton, New Jersey, USA. 
Reichel-Dolmatoff, G. 1971. Amazonian cosmos. Chicago University Press, Chicago, Illinois, USA.

Ross, E. B. 1978. Food, taboos, diet, and hunting strategy: the adaptation to animals in Amazon cultural ecology. Current Anthropology 19(1): 1-36. [online] URL: http:// www.jstor.org/stable/2741146 http://dx.doi.org/10.1086/201999

Sáenz-Arroyo, A., C. Roberts, J. Torre, M. Cariño-Olvera, and R. Enríquez-Andrade. 2005. Rapidly shifting environmental baselines among fishers of the Gulf of California. Proceedings of the Royal Society, Biological Science 272(1575): 1957-1962. [online] URL: http://rspb. royalsocietypublishing.org/content/272/1575/1957.full.pdf+ $\underline{\mathrm{html}}$ http://dx.doi.org/10.1098/rspb.2005.3175

Sandner, V. 2003. Myths and laws: changing institutions of indigenous marine resource management in Central America. Pages 269-300 in H. Breit, A. Engels, T. Moss, and M. Troja, editors. How institutions change: perspectives on social learning in global and local environmental contexts. Leske + Budrich, Opladen, Germany. http://dx.doi. org/10.1007/978-3-322-80936-0_15

Sirén, A. H., J. C. Cardenas, and J. D. Machoa. 2006. The relation between income and hunting in tropical forests: an economic experiment in the field. Ecology and Society 11 (1): 44. [online] URL: http://www.ecologyandsociety.org/ vol11/iss $1 /$ art $44 /$

Sutter, M. \& Kocher, M. G. 2007. Trust and trustworthiness across different age groups. Games Economic. Behavior 59: 364-382.

Turner, N. J., and F. Berkes. 2006. Coming to understanding: developing conservation through incremental learning in the Pacific Northwest. Human Ecology 34(4): 495-513. [online] URL: http://www.springerlink.com/content/c62kg2173g81542v/ fulltext.pdf http://dx.doi.org/10.1007/s10745-006-9042-0

Turner, N. J., M. B. Ignace, and R. Ignace. 2000. Traditional ecological knowledge and wisdom of aboriginal peoples in British Columbia. Ecological Applications 10(5): 12751287. [online] URL: http://www.esajournals.org/doi/ full/10.1890/1051-0761\%282000\%29010\%5B1275\%

3ATEKAWO\%5D2.0.CO\%3B2 http://dx.doi. org/10.1890/1051-0761(2000)010[1275:TEKAWO]2.0.CO;2

Tyran, J.-R., and L. P. Feld. 2006. Achieving compliance when legal sanctions are non-deterrent. Scandinavian Journal of Economics 108(1): 135-156. [online] URL: http:// onlinelibrary.wiley.com/doi/10.1111/j.1467-9442.2006.00444. x/pdf http://dx.doi.org/10.1111/j.1467-9442.2006.00444.x

Velez, M. A., J. J. Murphy, and J. K. Stranlund. 2010. Centralized and decentralized management of local common pool resources in the developing world: experimental evidence from fishing communities in Colombia. Economic
Inquiry 48(2): 254-265. [online] URL: http://onlinelibrary. wiley.com/doi/10.1111/j.1465-7295.2008.00125.x/pdf

Velez, M. A., J. K. Stranlund, and J. J. Murphy. 2009. What motivates common pool resource users? Experimental evidence from the field. Journal of Economic Behavior and Organization 70(3): 485-497. [online] URL: http://www. sciencedirect.com/science/article/pii/S0167268109000146

Vieco, J. J., and A. Oyuela. 1997. Identificación y evaluación de factores incidentes y limitantes de las actividades de piscicultura en las comunidades del Trapecio Amazónico. (Informe final). Instituto de Investigaciones Amazónicas, Universidad Nacional de Colombia, Sede Leticia.

Wagley, C. 1953. Amazon town. Macmillan, New York, New York, USA.

${ }^{[1]}$ It is possible that there is a publication bias with all studies on gender, age, and other socioeconomic characteristics since only those that find effects will later be published.

${ }^{[2]}$ This does not imply that money is not used in their daily lives. These communities are integrated to the market economy in several dimensions but reflect a dislike for monetary penalties. Therefore, as in any other economic experiment, we use monetary payments for individual decisions within the experiment as a means to reveal individual preferences (Croson 2005).

${ }^{[3]}$ The daily labor paid at the moment of this research in the region was equivalent to approximately U.S\$ 8 .

${ }^{[4]}$ Velez et al (2010) report results obtained with 300 resource users (mainly non-indigenous communities) in three distinct regions of Colombia. In those experiments the authors did not find differences in average behavior under limited open access across regions but did under different regulatory institutions. They emphasize the importance of replicating the same experimental design in different field contexts since "the field itself is a heterogeneous, and often challenging, place (2010:265)" where we need to understand which community or individual characteristics might explain variation. 


\section{APPENDIX}

Verbal Instructions

(Translated from Spanish)

Today we have _ people helping with this exercise: and

\section{First PART InSTRUCTIONS}

The objective of this exercise is to understand how the people of Puerto Nariño (from the urban area and the indigenous reserves) make decisions on the use of a natural resource, for example, fishing in Lake Tarapoto. We can decide whether we fish or not, and when to do so. We can also decide how many fish we catch each day; we can catch two or three "strings of fish" [common size and weight known by all in the community] or catch enough fish to bring back to the house or sell. These exercises are similar to those types of decisions.

In order to participate in this exercise, each paisano [compatriot, a common term among people who live in Puerto Nariño] will make decisions in a group with four other paisanos. However, the decisions will be individual; no one in your group must know about your decisions. Each paisano will be identified by a number throughout the exercise.

Today, there are __ groups of paisanos participating at the same time. Each group of paisanos will work separately, and the decisions of one group will not affect in any way those of the other groups. Each group will have different-colored sheets during the exercise, and one of us [researcher] will facilitate the development of the exercise in each group. In other words, one of us will be your group's monitor.

\section{$<$ Announce who will monitor which group.>}

In this exercise, each paisano can earn money based on his or her decisions and the decisions of the other paisanos in the group.

The reason we use money in this exercise is to represent real-life situations, since the fishing decisions you make have economic consequences.

You will play several rounds, and each round represents one day of fishing. 
In each round, each paisano will earn money according to his or her fishing decisions. At the end of the exercise, we will add the earnings of each round and pay you in cash. In order to receive your earnings, you must participate until the end of the exercise, which can take up to four hours.

We will now explain how to participate in the exercise. Please pay close attention to these instructions, remain seated, and do not talk to other paisanos during the exercise. If you have any questions, please raise your hand.

Your decisions are private and cannot be shown to the other paisanos.

\section{Earnings Table}

Next, we will hand out the EARNINGS TABLE, which shows what each paisano can earn according to the number of strings of fish he or she extracts from the lake. All paisanos have the same EARNINGS TABLE.

\section{$<$ Hand out the tables.>}

The tables you are receiving are exactly the same as the one in this poster.

The red numbers in the table are the number of pesos you can earn in each round depending on your decisions (what you decide to fish) and the decisions of the other paisanos in your group (what the others decide to fish). When each of you makes a decision on how many strings of fish to extract, you will not know the decisions of the other paisanos in your group.

In each round, each paisano must decide how many strings of fish to extract. In this exercise, this decision can be anything between 1 and 9 strings of fish. Your decision will be called MY AMOUNT FISHED. In the EARNINGS TABLE, the row MY AMOUNT FISHED shows the different quantities you can fish in each round: from 1 to 9 strings of fish. In other words, in this exercise, each paisano can fish a maximum of 9 strings of fish.

However, each paisano's earnings will depend on the decisions of the other paisanos in the group. In the EARNINGS TABLE, the decisions of the other paisanos are in the column AMOUNT FISHED BY OTHERS, which can be any number from 4 to 36 strings of fish. This number is the sum of the strings of fish extracted by the other paisanos in your group in each round. 
Remember that when each one of you makes a decision of how many strings of fish to extract, you will not know the decisions taken by the other paisanos in your group. The amount fished by the other paisanos will be known afterward, when we add the group's TOTAL.

We will add the number of strings of fish extracted by each paisano and give you the TOTAL of strings fished by the group.

The total strings fished by the group will show you the quantity fished by the rest of the group, but NOT the individual fishing decisions made by each person.

Let's look at some examples:

$<$ Do this exercise on the board.>

Remember there are 5 paisanos in your group deciding on how many strings of fish to extract.

Imagine that one paisano (Don Jose, for example) decides that MY AMOUNT FISHED is 4 strings of fish and the other four paisanos in the group also decide to fish 4 strings of fish each. We add the number of strings fished by each member of the group and announce to the group that the TOTAL amount fished by the group was 20 strings of fish $(4+4+4+4+4)$.

Because Don Jose decided to extract 4 strings of fish, he can calculate AMOUNT FISHED BY OTHERS like this:

$<$ Write this table on the board. $>$

\begin{tabular}{|l|c|}
\hline & How many strings did you decide to fish? \\
\hline Don Jose MY AMOUNT FISHED & 4 strings \\
\hline Paisano 2 & 4 strings \\
\hline Paisano 3 & 4 strings \\
\hline Paisano 4 & 4 strings \\
\hline Paisano 5 & 4 strings \\
\hline TOTAL FISHED BY THE GROUP & $4+4+4+4+4=20$ strings. \\
\hline TOTAL FISHED BY OTHERS & 20 strings $-4($ MY AMOUNT FISHED $)=16$ strings \\
\hline
\end{tabular}


Now you can calculate your earnings by looking where MY AMOUNT FISHED (4) and AMOUNT FISHED BY OTHERS (16) cross in the EARNINGS TABLE. In other words, where the column with MY AMOUNT FISHED 4 and the row with AMOUNT FISHED BY OTHERS 16 meet. In this case, we can see in the table that Don Jose's earnings would be 859 pesos.

However, if Don Jose extracts 4 strings of fish and the other paisanos in the group extract 2, 3, 7 and 8 each, we will add them and announce that the TOTAL fished by the group was $24(4+2+3+7+8)$. Because Don Jose decided to extract 4 , the AMOUNT FISHED BY OTHERS would be $24-4=20$.

$<$ Change the numbers in the table previously written on the board.>

\begin{tabular}{|l|c|}
\hline & How many strings did you decide to fish? \\
\hline Don Jose MY AMOUNT FISHED & 4 strings \\
\hline Paisano 2 & 2 strings \\
\hline Paisano 3 & 3 strings \\
\hline Paisano 4 & 7 strings \\
\hline Paisano 5 & 8 strings \\
\hline TOTAL FISHED BY THE GROUP & $4+2+3+7+8=24$ strings. \\
\hline TOTAL FISHED BY OTHERS & 24 strings $-4($ MY AMOUNT FISHED $)=20$ strings \\
\hline
\end{tabular}

In this case, as we can see in the EARNINGS table, Don Jose's earnings would be 754 pesos, as it is possible to see where MY AMOUNT FISHED (4) and AMOUNT FISHED BY OTHERS (20) cross. In other words, where the column with MY AMOUNT FISHED 4 and the row with AMOUNT FISHED BY OTHERS 20 meet.

On the other hand, if Jose chooses 8 and the others choose 3, 9, 7, and 6 each, the total amount fished would be 33 , the amount fished by others would be 25 , and Don Jose's earnings would be 679, as it is possible to see where MY AMOUNT FISHED (8) and AMOUNT FISHED BY OTHERS (25) cross. In other words, where the column with MY AMOUNT FISHED 8 and the row with AMOUNT FISHED BY OTHERS 25 meet. $<$ Change the numbers in the table previously written on the board.> 


\begin{tabular}{|l|c|}
\hline & How many strings did you decide to fish? \\
\hline Don Jose MY AMOUNT FISHED & 8 strings \\
\hline Paisano 2 & 3 strings \\
\hline Paisano 3 & 9 strings \\
\hline Paisano 4 & 7 strings \\
\hline Paisano 5 & 6 strings \\
\hline TOTAL FISHED BY THE GROUP & $8+3+9+7+6$ \\
\hline TOTAL FISHED BY OTHERS & 33 strings -8 (MY AMOUNT FISHED) $=25$ strings \\
\hline
\end{tabular}

As you can see, your earnings depend on your decisions and the decisions made by the rest of the group.

\section{Decision Cards}

In order to make your decisions in each round, you will receive a "Fishing Card" with the number that identifies each paisano. The Fishing Card is a small piece of paper like the one we will hand out next. <Distribute the cards to the participants.>

The card you are receiving is identical to the one on this poster.

In each round, you must write:

- The number of the round, which will be announced by us.

- The number of strings of fish you think the others will extract (a number between 4 and 36 strings). This is the sum of the strings of fish you believe the other 4 participants will extract. Remember that when you decide how many strings to fish, you do not know how much the other paisanos will be fishing. This information is interesting for us as it tells us what you are expecting about the amount the others will choose when making your decision.

- You must also write the amount you want to fish (the number of strings you decided to fish), a number between 1 and 9 .

After all the paisanos in your group have written down their decisions, we will pick up the cards of the 5 paisanos and add the TOTAL fished by the group. Once we know the 
TOTAL fished, we will announce it to the group so everyone can calculate the AMOUNT FISHED BY OTHERS. With this information and the number of strings of fish you extracted, you will be able to tell how much you earned in the EARNINGS TABLE.

It is very important for you to remember that your decisions are private and that you cannot show them to the other paisanos.

\section{Calculation Sheet}

Remember that you can earn money. Thus, you will receive a calculation sheet that looks like the one on this poster so it will be easy for you to keep track of your earnings. This sheet will allow each of you to calculate your earnings based on the number of strings of fish chosen by you and the number chosen by the others. The calculation sheet looks like this poster.

We will see how the calculation sheet is used with an example.

Remember, there are 5 paisanos deciding on how many strings to fish.

Suppose you decide to fish 4 strings.

You then have to write in the Fishing Card (the small piece of paper) the number 4 in MY AMOUNT FISHED.

You must also write this number on the calculation sheet in MY AMOUNT FISHED $=4$ (Column A).

All of you will be writing your fishing decision on two pieces of paper, the Fishing Card, which you will hand back to us, and the Calculation Sheet, where you will record your decisions and your earnings.

Remember also to write on the Fishing Card what you believe the other paisanos of your group will be fishing. For example, 18.

$<$ Write numbers on the board as participants write on their calculation sheets. $>$ 
After all of the paisanos in your group have made their decisions, we will pick up the cards from the 5 paisanos and add the numbers for the TOTAL amount fished by the group.

In this case, the sum of the group's decisions was 20 strings. You must write 20 in TOTAL amount fished (Column B). Now, in order to know the amount fished by the others, you have to subtract the amount fished by you from the total amount fished by the group (Column B minus Column A).

This result must be written in Column $\mathrm{C}$ AMOUNT FISHED BY OTHERS. In our example, the AMOUNT FISHED BY OTHERS is 16, $20-4$.

To calculate your earnings, you must use the EARNINGS TABLE. In this case, since MY AMOUNT FISHED is 4, and AMOUNT FISHED BY OTHERS is 16, my earnings are 859. You must write this information in MY EARNINGS IN THIS ROUND (Column D).

\section{Practice Rounds}

Before starting the exercise we will do a few practice rounds.

We will now start the exercise. 


\section{SECOND PART INSTRUCTIONS}

We will now start the second part of this exercise, which will last 10 rounds. In the second part, we will continue to make decisions about how much to fish, but there is now a rule that says that in each round each one of you is allowed to fish a maximum of two strings. If all the paisanos in your group extract only two strings each, there will be more earnings for the entire group.

However, you can decide how much to fish and whether you comply or not with this rule.

In order to supervise the compliance of this rule, there will be an inspection in each round.

The paisano who is inspected and is breaking the rule-in other words, is fishing more than 2 strings - will be sanctioned. This sanction implies that you will not be able to decide the amount you fish in the next round and you will have to extract only 1 string on that round. This means that in the next round you must fill in your card and hand it back to me, but in MY AMOUNT FISHED you must write "1 string."

No one else within the group will know if during the inspection a paisano was found breaking the rule. In other words, no one in the group will know if the inspected paisano was or was not sanctioned.

You will only be sanctioned if you are inspected and found to be fishing more than two strings. You are able to fish more than two strings, but if you do so and are inspected, you will be sanctioned. This means that you will not be able to decide how much to fish in the next round and you will be able to fish only one string in that round.

It would be very difficult to inspect the decisions made by every paisano in the group. This is why, after each paisano has decided on the amount he or she will fish and has handed back the Fishing Card, the inspection will be assigned through a raffle as follows:

In order to decide who will be inspected, we will pick a ball from a bag that contains 5 balls with the numbers of each participant and 5 blank balls. The number of the participant that appears on the ball will be inspected. If a blank ball is picked, no one will be inspected in that round. 
There will be one raffle per session; in other words, all groups must go at the same time.

If your participant number is picked, the monitor (one of us) will check how many strings you have fished in that round. If you fished more than two strings, you will be sanctioned and you will not be able to decide how much to fish in the next round and you will only be able to fish 1 string.

No one else in your group will know the result of this inspection. In other words, no one in the group will know if the inspected paisano was sanctioned or not.

You will only be sanctioned if you are inspected and you fished more than two strings. Therefore, you can decide how much to fish and if you comply or not with the rule in each round.

In each round, we will pick only one ball. If your number is picked, you will be inspected and no one else will be inspected in that round. If a blank ball is picked, there will be no inspection at all.

The ball that was picked will be returned to the bag. Therefore, anyone can be inspected more than once during the entire exercise. It is also possible for you to never be inspected if the ball with your number is never picked.

\section{Let's do some examples:}

\section{First example:}

If you fish 5 strings in round 1 , you will be breaking the rule because you will be fishing 3 more strings than the allowed amount of 2 strings.

If the ball with your number is picked, you will be inspected. Because you fished 5 strings, you will be sanctioned and in the next round you will not be able to decide how much to fish and you will have to fish 1 string only in that round.

In other words, in round 2, when you fill in your Fishing Card in MY AMOUNT FISHED you will have to write 1 string, and 1 string only.

If you are not inspected, you will not be sanctioned and will be able to decide how much to fish in the next round. 


\section{Another example:}

If you fish 2 strings, you are fulfilling the rule because the amount you fished is equal to the amount allowed.

Then, if your number is picked, you will be inspected. Because you only fished the allowed amount, you will not be sanctioned and you will be able to decide how much to fish in the next round. The other paisanos in your group will not know if you were sanctioned or not.

\section{Last example:}

If you fish 1 string, you are complying with the rule because the amount you fished is lower than the allowed maximum amount of 2 strings.

Then, if your number is picked, you will be inspected. Because the amount you fished is lower than the maximum amount permitted, you will not be sanctioned and you will be able to decide how much to fish in the next round.

Remember that you will only be sanctioned if you are inspected and the amount you fished is greater than 2 strings.

\section{Calculation Sheet}

We will now use a calculation sheet that is similar to the one in the previous exercise, but has two new columns.

The Columns A, B, C and D are used in the same way as in previous rounds, but there are two additional columns.

In Column E you must write if you were inspected or not during that round. The monitor will write YES if you are inspected (that means, if the ball with your number was picked) and you will write NO if your number is not picked.

Column F (Did I pick more than two strings?) will only be filled if you are inspected. The monitor will fill in this column only if your number is picked. In this column we will write if you are breaking the rule or not. 
Remember, if you are inspected and sanctioned for fishing more than 2 strings, you will not be able to decide how much you fish in the next round and you must only fish 1 sting. If you are not inspected, you must not write anything in column $\mathrm{F}$.

\section{Example:}

Imagine that the amount fished by Don Jose was 5 strings and the total fished by the group was 25 strings. Write this information down in the corresponding columns as in the previous rounds. In this case, the amount fished by the others is 20 (column C), and your earnings are 790. Write this information down in column D.

If Don Jose's number is picked, he will then be inspected and the monitor will write "YES" in column E. Because he was inspected and was breaking the rule because he fished 5 strings, then the monitor will write "YES" in column F.

This means that Don Jose will be sanctioned and will not be able to decide how much to fish in the next round and will be forced to fish only 1 string. In other words, in the next round, he must hand in his fishing card as the rest of the group but in MY AMOUNT FISHED he will write "1 string." In the "amount expected to be fished by others," you will continue to write what you expect the others will fish as in the previous rounds. 